\title{
DETERMINATING THE VALUE OF CAPITAL EXPENDITURE ALLOCATION IN INDONESIA LOCAL GOVERNMENT
}

\section{Mahameru Rosy Rochmatullah ${ }^{1 *}$, Rudy Hartanto ${ }^{2}$, Atwal Arifin ${ }^{3}$}

${ }^{1}$ Department of Economics, Universitas Muhammadiyah Surakarta Indonesia Jl. A Yani Tromol Pos 1 Pabelan, Surakarta, Central Java, Indonesia

${ }^{2}$ Otoritas Jasa Keuangan (OJK)- Direktorat Penelitian dan Pengaturan Perbankan Arsitektur Perbankan Indonesia (DPNP API).

${ }^{3}$ Komplek Perkantoran Bank Indonesia. Jln. M.H. Thamrin No. 2 Jakarta Pusat 10350

Department of Economics, Universitas Muhammadiyah Surakarta Indonesia

Jl. A Yani Tromol Pos 1 Pabelan, Surakarta, Central Java, Indonesia

*Corresponding E-mail : mrn122@ums.ac.id

Recieved: July 2016; Accepted: December 2016

\begin{abstract}
Capital expenditure allocation is aimed to preservation and expansion of local government fixed assets that provide long-term benefit. This paper investigates the factors that affect the capital expenditure allocation in Indonesian local government. Employing a panel pooled data-regression (fixed effect), our results reveal that local productivity, local funding, local budget requirement, and local establishment status are related to the value of capital expenditure. This research found that efficiency of capital expenditure management is related with fiscal dependence.
\end{abstract}

Keywords: Capital Expenditure, Local Productivity, Local Funding, Local Budget Reqirement, and Local Establishment Status.

JEL Classification: H72, H76, R58

\section{Introduction}

The practice of local capital expenditure management in Indonesia is contradictioning the existing laws and regulation. The studies on local government budget execution in Indonesia shows that in average, local government only realized $95 \%$ from their main budget for capital expenditure, and the average amount of total revenue allocated for capital expenditure is still below 30\% (DJPK, 2013). The regulation of home affairs ministry number 37 of 2012 regulates that in order to increase regional productivity, capital expenditures should be allocated minimum $30 \%$ of their revenues. The regulation indicates that local government tends to not trying for optimizing the allocation of capital expenditure in order to increase the productivity of the area.

Based on the problems described above, this research aims to re-examine the factors that affect the value of capital expenditure allocation in the local government of Indonesia. The analysis is performed by tested three (3) aspects: local productivity, funding, and budget requirement. The aspects of regional productivity will be proxied with PAD. Meanwhile, the funding aspect will be proxied with the General Allocation Fund (Dana Alokasi Umum-DAU), Specific Allocation Fund (Dana Alokasi Khusus-DAK), and the level of fiscal dependency. The aspects of the budgetary needs is proxied with the Territorial Coverage (Luas Wilayah-LW). This research use the perspective of local government characteristic 


\section{Jurnal Ekonomi Pembangunan, 17 (2), December 2016, 152-166}

differences in the form of local government types (Regency/Municipal), location (Java/non-Java), and the status of the areas establishment (main region/new autonomous) - with Tenure as control variables.

\section{Conceptual Framework}

\subsection{Local Government}

for Revenue and Expenditure (Anggaran Pendapatan dan Belanja Daerah-APBD)

APBD provides an overview about future financial plan on total income, expenditure, surplus/deficit, funding, and the work program and activities that will be performed by local government (Mahmudi, 2016: 168). The function of APBD is to be a tool used by local government to support the creation of public accountability. The concept of public accountability is associated with the increase of organizational performance, so that in the implementation of regional autonomy a performance oriented financial management and regional budgetary system is needed (Mardiasmo, 2004: 38).

The problems of budget arrangement in the local government in Indonesia is the conflict interest among the local government members. Widanaputra \& Mimba (2014) state that the process of participative budgeting on the local government in Indonesia tends to cause a budgetary slack due to the conflict of interest among the government members. The concept of transparency is necessary to generate budget that reflects local needs better. The commitment of budget transparency will create a thorough evaluation by the central government on local governments, both in the budgeting process and reporting (Sedmihradská, 2015).

Capital expenditure is a local government spending disclosed in APBD. The ideal practice of capital expenditure should follow the corridors regulated in the existing law and regulation in order to achieve an increase on local productivity. The increase in the local productivity can be achieved when local government does not depend on the transfer of revenue from the central government. (Galiński, 2015) - states that in Poland, the fluctuations of local capital expenditure affects the fluctuations of local debt. The study indicates that local debt has a positive correlation with local productivity. Local productivity is a key success of region in achieving a self-reliance, so there is a need for investment strategy in allocating capital expenditure into the local budget in Indonesia.

\subsection{Capital Expenditure}

Capital expenditure is a budgetary expenses for the acquisition of fixed assets and other assets which give a benefit for more than one accounting period (PP. 71/2010). The allocation of capital expenditures is aimed for the acquisition of the land, buildings, equipments, and intangible assets. Regulation No.13 of 2006 on Local Financial Management regulates that capital expenditure is used for expenses incurred in order to procure tangible fixed assets that have economic benefit for more than 1 (one) year to be used in government activities. The use of local government capital expenditure can be performed by expanding the development of productive fixed assets (Tuna et al., 2015).

The success of local government investment in order to realizing the capital expenditure requires an analysis on situation and condition of each region. The analysis process is expected to provide an accurate information for decisionmaking purposes. The accuracy of information is needed by the local politicians (people's representatives) and the local government in decision-making (Nogueira \& Jorge, 2015). Allocating capital expenditures based on an accurate information will geerate a more efficient investment decision. One of the indicators of financial management performance can be seen by the efficiency of the local revenue use (Susanto \& Djuminah, 2015). The efficiency of the allocation of capital expenditure is represented by the comparison between total amount of investment 


\section{Jurnal Ekonomi Pembangunan, 17 (2), December 2016, 152-166}

issued and the target of local revenue (Chapman \& Gorina, 2012).

A local government independence can be described by the value of the local debt and local government capital expenditure allocation. Burga et al. (1991) proved that local government independence can be seen from the interrelation between the local debt and the local capital expenditures. A small PAD will leads to low local government independence, so that the local governments will relies on the transfer of revenue from central government ( Bappenas \& UNDP, 2007).

\subsection{Local-Generated Revenue - PAD}

Theindependenceofaregioncanbedetermined by the productivity of its local government. The concept of New Public Management (NPM) has pointed out that productivity and efficiency is one of the indicators to assess local government performance (Johansson \& Siverbo, 2009). The improvements in the management of local productive assets is a positive effort in in order to enhance the productivity of local resources ( Benos \& Karagiannis, 2016). Regulation of the Minister of home affairs number 59 of 2007 regulates that the aims of capital expenditure is to fulfill the needs of a region for development and preservation of local fixed assets which have economic value for more than a year. The success of capital expenditure can be measured by the level of economic development of the region (Tuna et al. 2015). The relationship between the capital expenditure and the economic growth of a region is showed by the preservation and development of local productive assets (Tuasikal, 2008). The maintenance and development of the productive asset in the local area aim to increase localgenerated revenue (Pendapatan Asli DaerahPAD) (Harianto \& Adi, 2007).

The increase in government revenue is one of the measurements of the economic growth in a country (Roşoiu, 2015). In order to achieve an economic growth in the regions, local government needs to set a target of PAD in each fiscal year
(Moldovan \& Macarie, 2015). The tax paid by people in the area has a correlation with tax revenues of local self- government (Sipos, 2015). Data from the reports of budget realization of Regency/Municipal in Indonesia show that the majority of PAD is derived from taxes and levies. The income indicates that capital expenditure investment is affecting the local taxes and retributions. The income indicates that capital expenditure investment affects taxes and retributions. The larger the investment on capital expenditure in the local government means a larger contribution of retributions and taxes received by the local government.

The observation on the data of budget realization report of the Regency/Municipal in Indonesia shows that the contribution of PAD on total revenue is relatively small. The low PAD indicates low investment on capital expenditure, thus the income flow from retribution and taxes are not optimal. Local government has the right and obligation to manage local government business in their jurisdiction (Yunus et al., 2014). The management of the business can be performed by increasing the value of capital expenditure in an effort to increase the PAD. Bin \& Quan (2012) suggested that the improvement in the quality of investment management of local government expenditure can improve the quality and productivity service. Based on these explanations, researcher suspect that PAD has positive effect on the amount of capital expenditure allocation in the local government in Indonesia (H1).

\subsection{Fiscal Decentralization}

The economic growth of a region can be presented by the region's ability in obtaining capital in order to meet their needs (Ciccone \& Papaioannou, 2009). The Republic of Indonesia law no. 33 of 2004 regulates that the central government's fiscal decentralization policy aims to fulfill local government budget needs. One of the purposes of central government expenditure for regional spending is to reach a long-term fiscal balance (Lewis \& Oosterman, 2009). Baskaran 


\section{Jurnal Ekonomi Pembangunan, 17 (2), December 2016, 152-166}

(2010) proves that central government's fiscal decentralization policy in a significant amount will reduce local government's debt. Both of the studies illustrate that fiscal decentralization is not only aim to fulfill local government budget needs but also intended to fund local government's debt payment.

Transfer offunds from the central government to the local governments is the fundament of local government funding in achieving the principle of financial fairness in a country (Dash \& Raja, 2013). The data of local government financial statement in Indonesia show that the revenue transfer that dominates the financing of local budget is DAU and DAK. The policy on DAU aims to anticipate the gap of income among local governments and DAK aims to finance the special programs which become national priority (Wandira, 2013). This study will examine whether the policy of fiscal decentralization affects the amount of capital expenditure allocated by local government.

The concept of fiscal decentralization in this study is presented by DAU, DAK, and local government fiscal dependency ratio. The exact explanation can be described as follows:

a. General Allocation Fund - DAU

DAU aims to evenly distributing the local government capabilities in order to fund their needs as a form of decentralization implemented by central government (Law No.33/2004). Holtz-Eakin et al. (1994) explain that there is a strong relation between Central Government transfer and local government expenditure. The opinion indicates that capital expenditure is a part of APBD funded by DAU. DAU is referred as operational funds used for maintaining local government (Wilson et al., 2010). Based on these considerations, researcher suspect that DAU is a source for local government funding that influence the amount of capital expenditure allocation in the local governments in Indonesia (H2).

b. Specific Allocation Fund - DAK

DAK is a manifestation of the fiscal decentralization policy in Indonesia which aimed to fund specific activities of local government that are considered as national priorities (Law No. 33/2004). DAK is often used to maintain local government assets in the form of physical buildings and special program specified by a country (Wilson et al., 2010). Nuarisa (2013) states that there is a correlation between capital expenditure and national priority programs such as education programs, health, public services, and environment preservation. Empirically, Wandira (2013) proves that DAK has a significant effect on capital expenditure in all provinces of Indonesia. Based on these considerations, researcher suspect that DAK is a local government funding for special programs (national priority) that affects the amount of capital expenditure allocation in the local government in Indonesia (H3).

c. Fiscal Dependency

The level of local independence can be showed by the effort of the local government obtaining the fund for their budget. The independence of local government in China and United States is showed by the relation between the increase of expenditure and the interest rate for local debt (Du, 2015). The research indicates that the increase of local debt has an effect on the increase of local productivity. The observation on the local budgetary management in Indonesia shows a different tendency. The independence of local government in Indonesia can't be attained because of the revenue transfer from central government still dominates the local revenue ( Ihori \& Itaya, 2004).

Local revenue is the key factors in the success budgeting. The ambition of local government to reach the budget targets should be counterbalanced with the local revenue gain (Tuna et al., 2015). The attainment of local government budget targets toward the revenue acquisition is determined by rational budget management (Velazquez et al., 2010). Rationality in capital expenditure management can be represented with the reduction of income dependency level from the central government (Gemmell et al., 2013). 


\section{Jurnal Ekonomi Pembangunan, 17 (2), December 2016, 152-166}

Fiscal dependency can makes local governments find difficulties in developing their economic growth. Under this condition national issues faced by central government may affects local government budgeting process (Oprea \& Bilan, 2015). Local government fiscal dependency can be measured by calculating the ratio of fiscal dependency (KF). The parameter used in the calculation is a comparison of total income from transfer (IT) and total local government revenue (TR) (Mahmudi, 2016: 140). The calculation of the fiscal dependency ratio can be performed using following equation:

$$
\mathrm{KF}=\frac{\mathrm{IT}}{\mathrm{TR}}
$$

The level of fiscal dependency is an indicator of local government capability in generating their revenue. The excessive fiscal dependency is associated with wasteful expenditure. Grazhevska \& Virchenko (2014) prove that the factor which dominates the failure of fiscal decentralization policy in a country is the inefficiency in local government spending. The excessive fiscal dependency in local government in Indonesia is proved to reduce local government independence in generating their income (Siddiquee et al., 2012). Based on these considerations, researcher suspect that the higher the level of local government financial dependency, the higher the total fund allocated to capital expenditure, although the amount of funds allocated to capital expenditure does not guarantee the efficiency in its usage $(\mathrm{H} 4)$.

\subsection{Territorial Coverage}

The allocation of capital expenditure is based on local government needs for facilities and infrastructure, both for the smooth implementation of governmental duties and for public facilities. One of the variables that reflects the needs for the provision of facilities and infrastructure is LW (Law No.33/2004). Regions with a relatively wide territory will need more facilities and infrastructures to fulfil the requirements of proper public service. An area with wide rural areas will need to allocates more budget for developing facilities and infrastructures for public facilities (Escobal et al., 2015).

$\mathrm{LW}$ is one of determining factors in the allocation of regional needs. Yeung (2009) explaines that the LW of local government is a factor that determines the amount of revenue transfer from central government. The study shows that the revenue transfers from central government to the local government is strongly influenced by local government LW. Attolico (2014) proves that an extensive scope of territory needs more expansion and maintenance cost for local government fixed assets. Based on these two studies, researcher suspect that local government coverage in Indonesia is indicated by territorial coverage, affects the amount of the capital expenditure allocated in APBD (H5).

\subsection{Summary of Conceptual Framework}

The summary of conceptual framework is shown in the following Table 1.:

Table 1. Summary of Conceptual Framework

\begin{tabular}{cccc}
\hline No & $\begin{array}{c}\text { The Aspect } \\
\text { Analysis }\end{array}$ & Indicators & The Relationship \\
\hline & & $\begin{array}{l}\text { Capital expenditure is aimed to increase local government productivity } \\
\text { which represented by the growth of productive fixed assets owned } \\
\text { by a local government. The growth in productive fixed assets aims } \\
\text { to increase the PAD. Acquisition of PAD is a manifestation of assets } \\
\text { management quality funded by capital expenditures. }\end{array}$ \\
\hline
\end{tabular}




\begin{tabular}{|c|c|c|c|}
\hline No & $\begin{array}{c}\text { The Aspect } \\
\text { Analysis }\end{array}$ & Indicators & The Relationship \\
\hline \multirow[b]{2}{*}{2} & & DAU & $\begin{array}{l}\text { DAU is a representation of central government's efforts to resolve } \\
\text { the income gap among local government. DAU is one of local } \\
\text { government income to meet the needs of local expenditure, including } \\
\text { capital expenditure. The increase of DAU will have an impact on the } \\
\text { optimization of capital expenditure. }\end{array}$ \\
\hline & Funding & $\begin{array}{l}\text { Dependence } \\
\text { Ratio }\end{array}$ & $\begin{array}{l}\text { DAK aims to fund local government special programs such as the } \\
\text { national priority program. The implementation of special program } \\
\text { (national priority) needs an allocation of capital expenditure to } \\
\text { construct tangible fixed assets in the field of education, health, and } \\
\text { environment preservation. An increase of DAK will result in the } \\
\text { increase of capital expenditure allocation. } \\
\text { A high level of fiscal dependency indicating an inefficiency of } \\
\text { expenditure management in a local government. The higher the fiscal } \\
\text { dependency of the local government will cause an increase in the } \\
\text { value of capital expenditure, even without regarding the element of } \\
\text { efficiency. }\end{array}$ \\
\hline 3 & $\begin{array}{l}\text { Budgetary } \\
\text { Needs }\end{array}$ & $\begin{array}{l}\text { Territorial } \\
\text { Coverage }\end{array}$ & $\begin{array}{l}\text { A wide are coverage indicating a need of a large expenditure as well. A } \\
\text { wide region requires a large capital expenditure to fund the expansion } \\
\text { and maintenance of their productive assets. Local governments with a } \\
\text { wider LW have a relatively large allocation of capital expenditure. }\end{array}$ \\
\hline
\end{tabular}

\section{Research Method}

\subsection{The Population and Sampling Technique}

The population in this research is all local government of Regency/Municipal in Indonesia who published audited financial statements in the year of 2009-2013. The data used in this research are secondary data in the form of local government profile and financial statement of local government in Regency/Municipal level. The sample is taken using purposive sampling method; a sampling method performed by selecting research data that provide information needed in analysis process and hypothesis testing (Ghozali, 2011). Samples were selected based on the validity of the data and information obtained at each regency / municipal in Indonesia. This means, this study took a sample that has valid data and information

The data are collected from the official website of General Directorate of Financial Balance (http://djpk.depkeu.go.id), Audit Board of The Republic of Indonesia (http://bpk.go.id/), Ministry of Internal Affairs (http://kemendagri. go.id/)/ (http://otda.kemendagri.go.id/), Central Bureau of Statistics (http://bps.go.id), and
National Development and Planning Agency (http://bappenas.go.id).

\subsection{The Data Analysis Method}

The method used in analyzing the data is panel data regression analysis (fixed effect). Panel data regression worked out by merging cross-section and time series data, thus it can achieve a comprehensive testing from the over time variable (Widarjono, 2007). The regression model in this research is as follows:

$$
\begin{aligned}
& \left(\mathrm{BM}=\boldsymbol{\alpha}+\boldsymbol{\beta}_{1} \mathrm{PAD}+\boldsymbol{\beta}_{2} \mathrm{DAU}+\boldsymbol{\beta}_{3} \mathrm{DAK}+\boldsymbol{\beta}_{4} \mathrm{KF}+\right. \\
& \left.\boldsymbol{\beta}_{5} \mathrm{LW}+\boldsymbol{\beta}_{6} \mathrm{TPD}+\boldsymbol{\beta}_{7} \mathrm{LD}+\boldsymbol{\beta}_{8} \text { Tenure }+\boldsymbol{\varepsilon i}\right)
\end{aligned}
$$

Notes:

BM : Capital Expenditure

PAD : Local-Generated Revenue

DAU : General Allocation Fund

DAK : Specific Allocation Fund

KF : Fiscal Dependency

LW : Territorial Coverage

TPD : Type of Local Government - Regency or Municipal (Control Variable)

LD : The Location Area - Java or Non Java (Control Variable) 


\section{Jurnal Ekonomi Pembangunan, 17 (2), December 2016, 152-166}

Tenure: A Status Area - main region or new autonomous (Control Variable)

The hypothesis in this research is tested using simultaneous parameter regression test $(\mathrm{F}$ test), partial parameter regression test (t-test), and the coefficient of determination test (R2)

\section{Data Analysis and Discussion}

\subsection{The Description of Research Object}

The objects of this research are the LW from the local government profile, APBD from 20092013, and the audited local government financial report of Regency/Municipal in 2009-2013. The result of sampling using purposive sampling method can be seen in Table 2 . below.

\section{Table 2. Sampling Procedure}

\begin{tabular}{lc}
\hline \multicolumn{1}{c}{ Description } & Amount \\
\hline The number of observation using the & \\
data of local government profile, APBD, & \\
and local government financial report & 2.460 \\
in Regency/Municipal level in Indonesia & \\
for the period of 2009-2013 & \\
The number of incomplete data related & \\
to local government profile and the & 570 \\
recapitulation of audited financial & \\
statement for Regency/Municipal & \\
government in $2009-2013$ & \\
The number of observations used in \\
this research
\end{tabular}

\subsection{The Data Analysis and Hypothesis Testing}

a. Descriptive Statistic Test Result

The result of descriptive statistic test indicates that the average local government capital expenditure is $178.724,25$ (in million rupiahs). The minimum value of capital expenditure is in the municipal Government of Serang in the budget year of 2009, 19.316,73 (in million rupiahs). Meanwhile, the maximum capital expenditure is in the municipal Government of Banjarmasin in the budget year of 2012 in the amount of 2.499.133,16 (in million rupiahs). The average $\mathrm{PAD}$ is $83.913,20$ (in million rupiahs). The average $\mathrm{PAD}$ value indicates that the level of Regency/Municipal productivity is relatively low if compared with the funding from central government. DAU had an average value of 360.646,97 (in million rupiah). A third independent variable; DAK, has an average value of 51.443,84 (in million rupiahs). The average value of fiscal dependency ratio $(\mathrm{KF})$ is 0,8707 or $87,07 \%$ indicating that the high Regency/ Municipal government level of dependency towards central government. The average of local government LW is $3.666 \mathrm{Km}$.

b. Pooled Data Regression Analysis

The analysis model used in this study is pooled data regression - cross section fixed effect. This model is based on two (2) testing phase. The first phase, researchers conducted chow test to see the exact model among the models common effect or fixed effect. The results show that the chisquare value of 0.000 is less than 0.05 , so that the fixed effect model is more appropriate to use. The second phase, testing is done by using the Hausman test to ensure the most suitable model between the fixed effect model with cross section random effect model of. The test results show that the probability of 0.000 smaller than alpha 0.05 . This means that the test results supporting at an earlier phase that is most appropriate fixed effect model used in the analysis of data. In the end, the method of data analysis used in this study is panel data regression methods - fixed effect (test results attached).

c. Simultaneous Parameter Significance Test (Statistic F test)

Result of testing the simultaneous parameter significance $(\mathrm{F})$ indicates that the value of $\mathrm{F}$ significance is 0,000 . The value based on the test result that simultaneously all independent variables have significant influence on capital expenditure variable. This test indicates that regression model used can explain capital expenditure behavior in APBD. Table 3. is the result of $\mathrm{F}$ significancy test in this research: 
Avalaible online at http://journals.ums.ac.id

Jurnal Ekonomi Pembangunan, 17 (2), December 2016, 152-166

Table 3. The Result of Simultaneous Hypothesis Test

\begin{tabular}{|c|c|c|c|c|c|c|}
\hline \multicolumn{7}{|c|}{ ANOVA $^{\mathrm{a}}$} \\
\hline & Model & Sum of Squares & df & Mean Square & $\mathbf{F}$ & Sig. \\
\hline \multirow{3}{*}{1} & Regression & 16452843501106,422 & 12 & 1371070291758,868 & 78,968 & $0,000^{b}$ \\
\hline & Residual & 32589012168560,650 & 1877 & 17362286717,400 & & \\
\hline & Total & 49041855669667,070 & 1889 & & & \\
\hline \multicolumn{7}{|c|}{ a. Dependent Variable: BM } \\
\hline \multicolumn{7}{|c|}{ b. Predictors: (Constant), PAD, DAU, DAK, KF, LW, TPD, LD, Tenure } \\
\hline
\end{tabular}

Source: Processed secondary data

d. The Partial Parameter Significance Test (t-statistic test)

The test result of parameter significance-t test is presented in Tabel 4.

Tabel 4. The Result of Partial Coefficient Hypothesis Test (Panel Data Regression - Fixed Effect)

\begin{tabular}{|c|c|c|c|c|}
\hline \multirow{2}{*}{ Variable } & \multicolumn{2}{|c|}{ Coefficients } & \multirow{2}{*}{$\mathbf{t}$} & \multirow{2}{*}{ Prob. } \\
\hline & $\mathbf{C}$ & Std. Error & & \\
\hline (Constant) & $364.390,042$ & $28.242,664$ & 12,902 & 0,000 \\
\hline $\mathrm{PAD}$ & 0,298 & 0,020 & 14,685 & $0,000 *$ \\
\hline DAU & $-0,017$ & 0,026 & $-0,650$ & 0,516 \\
\hline DAK & 0,498 & 0,165 & 3,021 & $0,003^{* *}$ \\
\hline $\mathrm{KF}$ & $-323232,420$ & 28560,666 & $-11,317$ & $0,000 *$ \\
\hline LW & 8,681 & 0,651 & 13,334 & $0,000 *$ \\
\hline TPD & 4936,340 & 8842,678 & 0,558 & 0,577 \\
\hline $\mathrm{LD}$ & 8451,733 & 8996,148 & 0,939 & 0,348 \\
\hline Tenure & 15524,657 & 7182,334 & 2,162 & $0,031^{* *}$ \\
\hline
\end{tabular}

Description:

${ }^{*}$ Sig $1 \%,{ }^{*}$ Sig $5 \%$

PAD: Locally generated revenue, DAU: General allocation fund, DAK: Special allocation fund, KF: Fiscal dependency, LW: territorial coverage, TPD: The type of local government, LD: local government location, Tenure : A status area.

Source: Processed secondary data

Tabel 4. shows that PAD, DAK, fiscal dependency (KF), territorial coverage (LW), and a status area (Tenure) have significant effect on the allocation of capital expenditure (BM). The discussion of analysis result can be outlined as follows:

a) The analysis on regional productivity aspect shows that PAD has significant positive effect on capital expenditure. Thus, the acquisition of PAD is connected with the development of productive fixed asset in the local governments in Indonesia. The researcher prove that capital expenditure investment provide a contribution towards the acquisition of $\mathrm{PAD}$, even if its contribution is relatively low compared with the funds needed by local government cover their expenditure. The relatively small value of PAD shows that the management of capital expenditure still needs to be improved in 


\section{Jurnal Ekonomi Pembangunan, 17 (2), December 2016, 152-166}

order to gain optimal PAD (Bappenas and UNDP, 2007). One of the efforts that can be taken to increase PAD is increasing the innovation in the development of local government productive asset through capital expenditures.

b) The analysis on local government funding aspect shows that DAU variable has no effect on capital expenditure variable, whereas DAK variable has positive significant effect on BM variable. The result obtained indicates that capital expenditure tends to be utilized for funding regional programs (national priorities). Meanwhile, fiscal dependency variable has negative significant effect on capital expenditure variable. The test results shows different result with the initial research hypothesis (H5). This contradiction shows that the manifestation of the efficiency in managing local government capital expenditure is the increase of regional fiscal dependency ratio.

c) The LW factor is a determinant in determining the need of capital expenditure. The result of the testing shows that territorial coverage variable has positive significant effect on capital expenditure variable. This result gives an idea that a local government with relatively wide $\mathrm{LW}$ allocates more funds for capital expenditure.

d) The analysis of regional characteristic differences perspective can be shown in the test on this research control variable. The test result shows that Tenure variable has an influence on the allocation of fund for local government capital expenditure.
Thus, there are differences of policy between the new autonomous region and main region in allocating capital expenditure. The observation performed on the value of capital expenditure in Regency/Municipal financial report data shows that the value of capital expenditure allocation in the new autonomous region tend to be higher than the main region. However, the significance value of control variable TPD and LD are above the predetermined significance value (5\%). The test result shows that the type of local government region (Regency/Municipal) and local government location (Java/outside java) have no effect towards regional capital expenditure.

The testing results pose a change toward regression equation model formulated earlier. The regression equation based on the testing results can be formulated as follows:

$(\mathrm{BM}=364390+0,298 \mathrm{PAD}+0,498 \mathrm{DAK}-$
$323232 \mathrm{KF}+8,681 \mathrm{LW}+15524$ Tenure $)$

e. The Test of the Coefficient of Determination The result of coefficient of determination testing can be shown by Adjusted $\mathrm{R}^{2}$ value of 0.331 or $33.1 \%$. The result is a measure that shows that independent variables affect the dependent variable for $33.1 \%$. However, there are another independent variables outside the research model that affect the dependent variable for $66.9 \%$. Here is the result of coefficient of determination test:

Table 5. The test result of coefficient of determination

\begin{tabular}{|c|c|c|c|c|c|}
\hline \multicolumn{6}{|c|}{ Model Summary ${ }^{b}$} \\
\hline Model & $\mathbf{R}$ & R Square & $\begin{array}{l}\text { Adjusted R } \\
\text { Square }\end{array}$ & $\begin{array}{c}\text { Std. Error of the } \\
\text { Estimate }\end{array}$ & Durbin-Watson \\
\hline 1 & $0,579^{\mathrm{a}}$ & 0,335 & 0,331 & 131766,03021 & 1,691 \\
\hline \multicolumn{6}{|c|}{ a. Predictors: (Constant), PAD, DAU, DAK, KF, LW, TPD, LD, Tenure } \\
\hline \multicolumn{6}{|c|}{ b. Dependent Variable: BM } \\
\hline
\end{tabular}

Source: Processed secondary data 


\section{Jurnal Ekonomi Pembangunan, 17 (2), December 2016, 152-166}

\section{Conclusion and Implication 4.1. Conclusion}

This research aims to analyze the factors that affects the determination of fund allocated to capital expenditure in local government. The analysis are performed by considering regional productivity aspect, regional funding aspect, and regional budget needs aspect. The result of analysis on productivity aspects shows the connection between PAD and local government capital expenditure. PAD is a measurement of local government productivity that is affected by the innovation of local government in developing productive assets. The improvement in innovation of local government productive asset development leads to the increase of fund allocated for capital expenditure.

An analysis on regional funding aspect shows the connection between DAK and regional fiscal dependency, and local government capital expenditure. The analysis result obtained from testing the fiscal dependency factor and funding factor (DAK) shows that the fiscal dependency of local government to fund their capital expenditure caused by the efficiency in deciding the value of capital expenditure funded by DAK. The efficient funding of capital expenditure results in the small return received by the local government.

The aspect of central government funding (transfer revenue) is the largest contributor in funding local government expenditure. However, we found no evidence on the influence of DAU on the allocation of capital expenditure in Regency/ Municipal government in Indonesia. The test results obtained show that the DAU variable has no effect on capital expenditure variable. DAU tends to be used for local government activities besides infrastructure development, in the other word more for routine expenditure (DJPK, 2013).

The analysis on the aspect of local government regional budget needs shows the connectedness between local government LW and the totalvalue of local government capital expenditure. One of the factors that determine local government needs of capital expenditure is the local government LW. However, the testing on control variable shows the difference between the value of capital expenditure allocation in a new autonomous region with the main region. The new autonomous area tends to need more capital expenditure than the main region.

In the end, conclusion can be drawn based on the result of analysis performed. This research concludes that several factors affect the determination of the value of local government capital expenditure allocation in Indonesia, the variables are: the level of local government productivity indicates by PAD, regional funding for special programs (national priorities) indicates by DAK, the efficiency in managing capital expenditure, the area coverage of local government, and the regional characteristic difference proxied by the difference of regional establishment status (main region/the new autonomous area).

\subsection{Implications}

This research try to learn the process of regional capital expenditure management. The analysis result gives an overview of the process of regional capital expenditure allocation that consider regional productivity factor, the efficiency of funding, territorial, and the status of a regional establishment. This research is expected to provide a reference for future research. This research can become learning material for local government in order to increase the benefit of capital expenditure.

\section{Note}

This research uses data from valid and relevant sources. Following is the metadata explanation for this research: 
Avalaible online at http://journals.ums.ac.id

Jurnal Ekonomi Pembangunan, 17 (2), December 2016, 152-166

\section{Metadata}

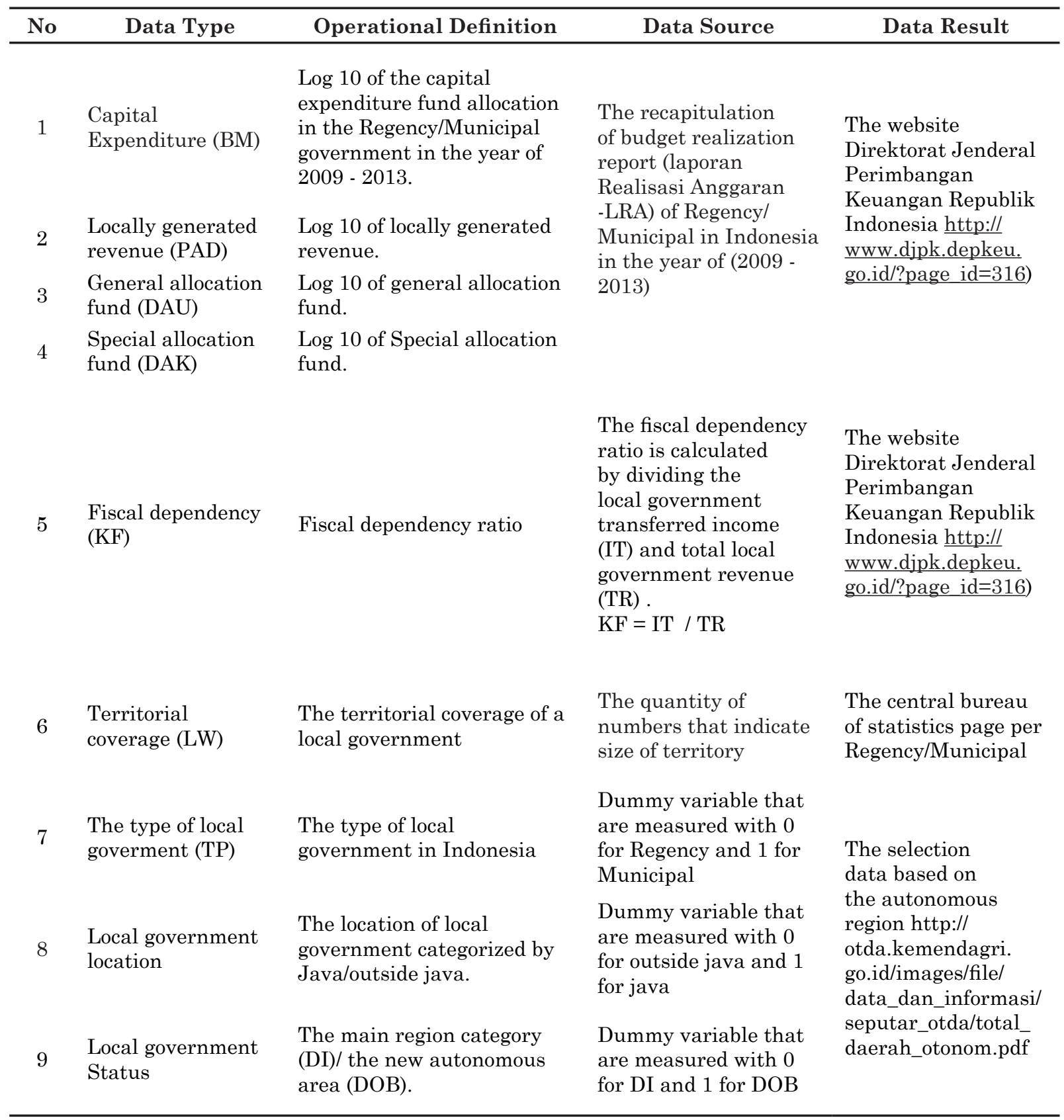

\section{References}

Attolico, A., 2014. Building Resilience Through Territorial Planning: The Experience of Province of Potenza. Procedia Economics and Finance, 18 (September), pp.528535. Availableat:http://www.sciencedirect.com/ science/article/pii/S2212567114009721.

Bappenas. \& UNDP., 2007. Studi Evaluasi
Pemekaran Daerah. Building and Reinventing Decentralized Governance Project Badan Perencanaan Pembangunan Nasional Bekerjasama dengan United Nation Development Program. July, 4 Version. Jakarta. Available at : http:// bappenas.go.id/files/6013/8785/4695/Studi_ Evaluasi_Pemekaran_Wilayah-2007.PDF 


\section{Jurnal Ekonomi Pembangunan, 17 (2), December 2016, 152-166}

Baskaran, T., 2010. On the link between fiscal decentralization and public debt in OECD countries. Public Choice, pp.351-378. DOI 10.1007/s11127-009-9570-4.

Benos, N. \& Karagiannis, S., 2016. Do Education Quality and Spillovers Matter? Evidence on Human Capital and Productivity In Greece. Economic Modelling. 54 : 4, pp 563-573. Available at : http://www.sciencedirect.com/ science/article/pii/S0264999316000274.

Bin, Y. \& Quan, L., 2012. Construction Financing Problem of Local Government in China. Physics Procedia, pp.1773-1780. Available at: http://dx.doi.org/10.1016/j. phpro.2012.02.261.

Burga, B., McDonald, S. \& Thomson, N., 1991. Grants Commission Assessment of Local Government Debt Servicing and Capital Expenditures. Economic Analysis and Policy, pp.15-28. Available at: http:// linkinghub.elsevier.com/retrieve/pii/ S0313592691500023.

Chapman, J. \& Gorina, E., 2012. Effects of the Form of Government and Property Tax Limits on Local Finance in the Context of Revenue and Expenditure Simultaneity. Public Financial Publication , pp.19-45. Available at : http://onlinelibrary.wiley.com/ doi/10.1111/j.1540-5850.2012.01022.x/full.

Ciccone, A. \& Papaioannou, E., 2009. Human capital, the structure of production, and growth. The Review of Economics and Statistics, 91(1), pp.66-82. Available at : https://www.dartmouth.edu/ elias/ hcproduction07aug07.pdf

Dash, B.B. \& Raja, A. V, 2013. Intergovernmental Transfers and Tax Collection in India : Does the Composition of Transfers Matter?. Public Financial Publication, pp.93-116. DOI: $10.1111 / \mathrm{j} .1540-5850.2013 .12010 . x$.

DJPK. 2013. Laporan Evaluasi Belanja Modal Daerah. Kementerian Keuangan Republik
Indonesia. Jakarta. Available at: http://www. djpk.kemenkeu.go.id/web/attachments/ article/363/evaluasi $\% 20$ belanja $\% 20$ modal\%20koreksi\%20akhir2\%20kecil.pdf.

Du, L., 2015. Positive Correlation between Government Expenditure and Real Interest Rate: Testing Ramsey Model Based on American and Chinese Data. Procedia Economics and Finance, pp.202-212. Available at: http://linkinghub.elsevier.com/ retrieve/pii/S2212567115012873.

Escobal, J., Favareto.A., Aguirre. F. \& Ponce. C., 2015. Linkage to Dynamic Markets and Rural Territorial Development in Latin America. World Development, pp.44-55. Available at: http://linkinghub.elsevier.com/ retrieve/pii/S0305750X14002824.

Galiński, P., 2015. Determinants of Debt Limits in Local Governments: Case of Poland. Procedia - Social and Behavioral Sciences, 213, pp.376-382. Available at: http://linkinghub.elsevier.com/retrieve/pii/ S1877042815059091.

Gemmell, N., Kneller, R. \& Sanz, I., 2013. Fiscal decentralization and economic growth: Spending versus revenue decentralization. Economic Inquiry, 51, pp.1915-1931. Available at: http://www.socsci.uci. edu/ jkbrueck/course\%20readings/Econ\%20 272B\%20readings/gem mell-kneller-sanz. pdf.

Grazhevska, N. \& Virchenko, A., 2014. Special Features of the Ukrainian Fiscal Policy Transmission Mechanism under Increasing Macroeconomic Instability. Procedia Economics and Finance, pp.680-689. Available at: http://dx.doi.org/10.1016/ S2212-5671(14)00856-9.

Harianto, D. \& Adi, P. H., 2007. Hubungan Antara Dana Alokasi Umum, Belanja Modal, Pendapatan Asli Daerah Dan Pendapatan Per Kapita. Simposium Nasional Akuntansi X. Makassar, pp.1-26. Available at: 


\section{Jurnal Ekonomi Pembangunan, 17 (2), December 2016, 152-166}

http://multiparadigma.lecture.ub.ac.id/ files/2014/10/SNA-10-ASPP-15.pdf

Holtz-Eakin, D., Rosen, H. S. dan Tilly. S., 1994. Intertemporal Analysis of State an Local Government Spending:Theory and Test. Journal of Urban Economics 35: 159-174. Available at: http://www.nber.org/papers/ w4261\#.

Ihori, T. \& Itaya, J. C., 2004. Fiscal Reconstruction and Local. International Tax and Public Finance, 11, 55-67, pp.55-67. DOI : 10.1023/B:ITAX.0000004777.75405.8c.

Johansson, T. \& Siverbo, S., 2009. Explaining The Utilization of Relative Performance Evaluation in Local Government: A MultiTheoretical Study Using Data from Sweden. Financial Accountability \& Management, 25(2) 0267 - 4424. DOI: $10.1111 / \mathrm{j} .1468$ 0408.2009.00474.x

Lewis, D. L. \& Oosterman., 2009. The Impact of Decentralization on Subnational Government Fiscal Slack in Indonesia. Public Budgeting and Finace,3(3), pp.27-47. Available at : http://documents.worldbank. org/curated/en/2009/01/15957051/impactdecentralization-subnational-governmentfiscal-slack-indonesia\#

Mardiasmo., 2004. Otonomi dan Manajemen Keuangan Daerah. Edisi Kedua. Andi Offset. Yogyakarta.

Mahmudi., 2016. Analisis laporan Keuangan Pemerintah Daerah. Edisi Ketiga. Sekolah Tinggi Ilmu Manajemen YKPN. Yogyakarta.

Moldovan, O. \& Macarie, F.C., 2015. Reducing Uncertainty in Romanian Public Finances: Forecasting Models for Revenue Collection. Procedia Economics and Finance, pp.15501567. Available at: http://linkinghub.elsevier. com/retrieve/pii/S2212567115015452.

Nogueira, S.P.S. \& Jorge, S.M.F., 2015. Explanatory factors for the use of the financial report in decision-making: Evidence from Local Government in Portugal. Revista de Contabilidad - Spanish Accounting Review xxx (xx). Available at: http://dx.doi. org/10.1016/j.rcsar.2015.09.002.

Nuarisa, S. A., 2013. Pengaruh PAD, DAU, dan DAK terhadap Pengalokasian Anggaran Belanja Modal. Accounting Analysis Journal 2 (1):89-95. Available at: http://journal. unnes.ac.id/artikel_sju/aaj/1163.

Oprea, F. \& Bilan, I., 2015. An Evaluation of the Economic and Financial Crisis's Impact on Local Budgetary Aggregates: The Romanian Case. Procedia Economics and Finance, pp.467-477. Available at: http:// www.sciencedirect.com/science/article/pii/ S2212567115000982.

Peraturan Pemerintah Republik Indonesia Nomor 71 Tahun 2010. Standar Akuntansi Pemerintahan. Jakarta. http://djpk.depkeu. go.id

Peraturan Menteri Dalam Negeri Republik Indonesia Nomor 37 tahun 2012. Pedoman Penyusunan Anggaran Pendapatan dan Belanja Daerah Tahun Anggaran 2013. Jakarta. http://kemendagri.go.id

Peraturan Menteri Dalam Negeri Nomor 13 Tahun 2006. Pedoman Pengelolaan Keuangan Daerah. http://otdakemendagri. go.id.

Roşoiu, I., 2015. The Impact of the Government Revenues and Expenditures on the Economic Growth. Procedia Economics and Finance, 32(15), pp.526-533. Available at: http://linkinghub.elsevier.com/retrieve/pii/ S2212567115014288.

Sedmihradská, L., 2015. Budget Transparency in Czech Local Government. Procedia Economics and Finance, pp. 598-606. Available at: http://linkinghub.elsevier.com/ retrieve/pii/S2212567115007741.

Siddiquee, N.A., Nastiti, D. \& Sejati, N.A., 2012. Regional Autonomy and Local Resource 


\section{Jurnal Ekonomi Pembangunan, 17 (2), December 2016, 152-166}

Mobilization in Eastern Indonesia: Problems and Pitfalls of Fiscal Decentralization. Asian Affairs: An American Review, pp.44-68. DOI: $10.1080 / 00927678.2012 .649636$.

Sipos, A., 2015. Determining factors of tax-morale with special emphasis on the tax revenues of local self-governments. Procedia Economics and Finance, pp. 758 - 767. Available at : $\quad$ http://www.sciencedirect.com/science/ article/pii/S2212567115013258.

Susanto, D. \& Djuminah, 2015. The Usefulness of Local Government Financial Statements for Regional Development Planning Process (An Empirical Study Against the Head of the Regency Development Planning Agencies in Java and Madura). Procedia - Social and Behavioral Sciences, 211, pp.75-80. Available at: http://linkinghub.elsevier.com/ retrieve/pii/S1877042815053525.

Tuna, K., Kayacan, E. \& Bektaú, H., 2015. The Relationship Between Research \& Development Expenditures and Economic Growth: The Case of Turkey. Procedia - Social and Behavioral Sciences, 195(195), pp.501507. Available at: http://www.sciencedirect. com/science/article/pii/S1877042815037349.

Tuasikal, A., 2008. Pengaruh DAU, DAK, PAD, dan PDRB Terhadap Belanja Modal Pemerintah Daerah Kabupaten/Kota di Indonesia. Jurnal Telaah dan Riset Akuntansi 1 (2): 142-155. Available at: http://www.jurnal.unsyiah.ac.id/index.php/ TRA/article/viewFile/299/284.

Undang-Undang Republik Indonesia Nomor 33 Tahun 2004. Perimbangan Keuangan Antara Pemerintah Pusat dan Pemerintah Daerah. Jakarta. http://djpk.depkeu.go.id.

Velazquez, J.A.D., Ladesma, J.D.E. \& Rodriguez, J.V.P., 2010. Models of Municipal
Budget Allocation: Empirical Data from Spanish Municipalities. Public Budgeting and Finance, pp.24-46. Available at : http://dx.doi.org/10.1111/j.15405850.2010.00955.x.

Wandira, A. G., 2013. Pengaruh PAD, DAU, DAK dan DBH terhadap Pengalokasian Belanja Modal. Accounting Analysis Journal 1 (3): 45-51. Available at : http://journal.unnes. ac.id/artikel_sju/aaj/1158.

Widanaputra, A. A. \& Mimba, N.P.S.H., 2014. The Influence of Participative Budgeting on Budgetary Slack in Composing Local Governments' Budget in Bali Province. Procedia - Social and Behavioral Sciences, 164, pp.391-396. Available at: http:// linkinghub.elsevier.com/retrieve/pii/ S1877042814059138.

Widarjono. Agus . 2007. Ekonometrika Teori dan Aplikasi untuk Ekonomi dan Bisnis. Ekonisia. Yogyakarta.

Wilson, E.R., Reck, J.L. \& Kattelus, S.C., 2010. Accounting for Governmental and Nonprofit Entities. Fifteenth Edition. McGraw Hill Irwin. United Stated. ISBN - 13: 978-0-07337960-9.

Yeung, R., 2009. The Effects of Fiscal Decentralization on the Size of Government : A Meta-Analysis. Public Budgeting and Finance, pp.1-23. Available at: http://dx.doi. org/10.1111/j.1540-5850.2009.00940.x.

Yunus, O.M, Bustaman, H. A. \& Rashdi, W.F.A.W.M., 2014. Conducive Business Environment: Local Government Innovative Work Behavior. Procedia - Social and Behavioral Sciences, 129, pp.214-220. Available at: http://www.sciencedirect.com/ science/article/pii/S1877042814028511. 
Jurnal Ekonomi Pembangunan, 17 (2), December 2016, 152-166

\section{Appendix}

\section{Appendix 1. The Result of Chow Test}

Redundant Fixed Effects Tests

Equation: FE

Test cross-section fixed effects

$\begin{array}{lll}\text { Statistic } & \text { d.f. } & \text { Prob. } \\ 3.054921 & (377,1502) & 0.0000 \\ 1074.572844 & 377 & \mathbf{0 . 0 0 0 0}\end{array}$

Cross-section $\mathrm{F}$
Cross-section Chi-square

Cross-section fixed effects test equation:

Dependent Variable: BM

Method: Panel Least Squares

Date: 11/29/16 Time: 08:11

Sample: 20092013

Periods included: 5

Cross-sections included: 378

Total panel (unbalanced) observations: 1890

\begin{tabular}{lrrrl}
\hline Variable & Coefficient & Std. Error & t-Statistic & Prob. \\
\hline C & 382566.8 & 27530.73 & 13.89599 & 0.0000 \\
PAD & 0.316998 & 0.020058 & 15.80418 & 0.0000 \\
DAU & -0.028472 & 0.015023 & -1.895213 & 0.0582 \\
DAK & 0.717031 & 0.143892 & 4.983101 & 0.0000 \\
KF & -340455.8 & 28947.50 & -11.76115 & 0.0000 \\
LW & 8.588114 & 0.659757 & 13.01708 & 0.0000 \\
TPD & 5839.287 & 9006.081 & 0.648372 & 0.5168 \\
LD & 3977.993 & 8675.572 & 0.458528 & 0.6466 \\
Tenure & 17094.30 & 7236.749 & 2.362152 & 0.0183 \\
R-squared & 0.309751 & Mean dependent var & 178514.4 \\
Adjusted R-squared & 0.306813 & S.D. dependent var & 161097.0 \\
S.E. of regression & 134126.0 & Akaike info criterion & 26.45570 \\
Sum squared resid & $3.38 \mathrm{E}+13$ & Schwarz criterion & 26.48213 \\
Log likelihood & -24965.18 & Hannan-Quinn criter. & 26.46543 \\
F-statistic & 105.4009 & Durbin-Watson stat & 1.376995 \\
Prob(F-statistic) & 0.000000 & & & \\
\hline
\end{tabular}

Appendix 2. The result of Hausman test

Correlated Random Effects - Hausman Test

Equation: HAUSMAN

Test cross-section random effects

Test Summary

Cross-section random

Chi-Sq. Statistic

76.501032

Cross-section random effects test comparisons:

\begin{tabular}{ccccc}
\hline Variable & Fixed & Random & Var(Diff.) & Prob. \\
\hline PAD & 0.277183 & 0.298010 & 0.000081 & 0.0204 \\
DAU & -0.027956 & -0.031743 & 0.000596 & 0.8768 \\
DAK & 0.545370 & 0.679181 & 0.010754 & 0.1969 \\
KF & -266216.121604 & -293615.203600 & 70180694.328819 & 0.0011 \\
LW & 4.513330 & 6.803516 & 0.176539 & 0.0000 \\
TPD & -18830.451228 & -3355.231287 & 21549192.058977 & 0.0009 \\
LD & 154649.606159 & 8258.894517 & 1617415647.534469 & 0.0003 \\
Tenure & -572.821286 & 9038.437754 & 10213287.663338 & 0.0026 \\
\hline
\end{tabular}

